\title{
The long-term evolution of urban waters and their nineteenth century transformation in European cities. A comparative environmental history
}

\author{
Verena Winiwarter ${ }^{1}$ - Gertrud Haidvogl ${ }^{2}$ - Severin Hohensinner ${ }^{2}$. \\ Friedrich Hauer $^{1} \cdot$ Michael Bürkner ${ }^{1}$
}

Received: 16 July 2015/Accepted: 27 July 2016/Published online: 26 September 2016

(C) The Author(s) 2016. This article is published with open access at Springerlink.com

\begin{abstract}
The nineteenth century was marked by a fundamental change in city-river relations. The environmental history perspective employed in this article illustrates how the complex interplay between the diverse natural and societal endowment of four European cities (Brussels, Lyon, Munich, and Vienna) shaped urban aquatic networks. Throughout the long-term co-evolution of the urbanites and their aquatic network, different sources of waterpower in the cities had led to differences in use and transformation. In the nineteenth century, industrialization induced a shift to a fossil energy regime in all four study sites. Population growth and urbanization required new areas for housing, industry, and trade, as well as new means of sanitation. Main drivers of the transformation included river engineering, flood protection dikes, advances in the fight against epidemic cholera, improved sanitation, water supply, and sewage networks. By the beginning of the twentieth century, the water networks of the four cities were thoroughly transformed. Despite different natural endowments, the four cities had grown increasingly similar, using water mainly as a metabolic substance for consumption and waste removal. Smaller watercourses had become part of the subterranean sewage network; larger ones were often vaulted or encased by flood protection walls leaving legacies for urban authorities in the twentieth century and beyond.
\end{abstract}

Keywords Urban rivers · Industrial revolution · Brussels · Lyon · Munich · Vienna

Introductory paper for the thematic issue "Comparing Urban Rivers" (Water History).

Verena Winiwarter

verena.winiwarter@uni-klu.ac.at

1 Faculty of Interdisciplinary Studies, Institute of Social Ecology, Alpen-Adria-Universität Klagenfurt, Klagenfurt, Austria

2 Institute of Hydrobiology and Aquatic Ecosystem Management, University of Natural Resources and Life Sciences Vienna, Vienna, Austria 


\section{Introduction}

By the beginning of the twentieth century, fundamental changes had taken place in most European cities. Smaller watercourses had become part of subterranean sewage and drainage networks. Larger ones were often vaulted in elaborate artificial beds or encased by flood protection walls. If flowing above ground, they were barely within the reach of townspeople. Richly documented empirical studies for several cities in this thematic issue address aspects of the transition of societal water use and the city-water-system on a spatially explicit level. The studies reveal different trajectories and fundamental differences in the factors that influenced the transition. The diverse nature of urban waters, specific resource demand, and extraction technologies translated into different uses of urban waters and affected them in different ways. Social dynamics unfolded in conjunction with the dynamic city-water-system. Various actors in changing power relations influenced the balance between potentially conflicting uses, but the urban situation also was and remains embedded in a framework of external forces influencing change, such as climate, war, or technology.

A comparison of Vienna with Lyon, Munich, and Brussels can shed light on both particulars and similarities with respect to city-water dynamics. Different aquatic endowments and constraints made a difference in the process of transformation that took place in the nineteenth century that is commonly known as the Industrial Revolution. Water use is one of the six main flows, which — together with societal stocks-make up the biophysical dimensions of social systems. It was particularly deeply affected by this transition (Fischer-Kowalski and Haberl 2007). All four cities are situated on the upper or middle section of rivers. In pre-industrial times, rivers served as major urban transport routes connecting the city to supply and demand regions.

Figure 1 gives an overview of the cities and the watercourses we studied. Using these cases, we offer an environmental history framework for the study and interpretation of the development of European cities located close to rivers. We compare the modernization and industrial transformation of Vienna, Lyon, Munich, and Brussels as a study of co-evolution, paying attention to differences in the aquatic networks as well as to differences in the societal preconditions.

The four cities illustrate how driving forces on macro- and local levels led to four distinct cases of industrial transformation of cities and rivers, which became increasingly like one another in the process. Diverse natural endowments and natural constraints played important roles in the locally distinct pathways towards this homogenization. The four cities, faced with different types of arrangements overcame their resistance in different ways. However, while there were distinct sources of waterpower in the cities, leading to differences in use and transformation, all four cities ended with the same dependence on fossil energy and their water networks thoroughly changed and made more similar. Water

\begin{tabular}{|l|l|l|l|}
\hline City & River & Size (average discharge) & Type \\
\hline Brussels & Senne & small $\left(5 \mathrm{~m}^{3} / \mathrm{s}\right)$ & lowland \\
\hline Lyon & Rhône & large $\left(1030 \mathrm{~m}^{3} / \mathrm{s}\right)$ & alpine \\
\hline Lyon & Saône & medium to large $\left(480 \mathrm{~m}^{3} / \mathrm{s}\right)$ & lowland \\
\hline Munich & Isar & medium $\left(64 \mathrm{~m}^{3} / \mathrm{s}\right)$ & alpine \\
\hline Vienna & Danube & large $\left(1910 \mathrm{~m}^{3} / \mathrm{s}\right)$ & alpine/montane \\
\hline Vienna & Wien River & small $\left(1,3 \mathrm{~m}^{3} / \mathrm{s}\right)$ & montane \\
\hline Vienna & $\begin{array}{l}\text { Währingerbach, Wr. Neustädter } \\
\text { Shipping Canal }\end{array}$ & small $\left(0.04\right.$ and $\left.1.3 \mathrm{~m}^{3} / \mathrm{s}\right)$ & $\begin{array}{l}\text { montane } / \text { artificial- } \\
\text { lowland }\end{array}$ \\
\hline
\end{tabular}

Fig. 1 Characteristics of the aquatic endowment of the studied cities, situation in 2014 
use was relegated to a substance for consumption and a carrier for waste removal. Cities became central to an industrial society based on coal, railways, and specialized mass production of uniform goods for large and distant markets. They were growing at unprecedented speed both in terms of population and of spatial extension.

To move onto this accelerated path, urbanites welded together infrastructure systems out of watercourses, created networks of subterranean sewers, built pipelines to transport clean drinking and process water from afar, and regulated flowing waters to optimize particular functions. Apart from creating urgently needed space for housing, one important factor driving city governments towards costly regulation projects was the need to protect the cities from disease and floods by systematic regulation and flood protection dikes, in combination with a complex network of sewers with small streams often vaulted and integrated into the sewage system. Urban administrations did so at considerable cost and created considerable legacies. The processes did come with side effects and led to a profound transformation not only of the economy but also of city ecologies. However, in the layout of the cities, traces of earlier uses of the rivers and streams remained and some are still visible today.

Main drivers of the nineteenth century transformation of urban aquatic ecosystems include river engineering, flood protection dikes, and new medical knowledge regarding sanitation, which led to technologically enabled centralized water supplies and sewage networks. Other drivers played a role as well. It is clear that a changing perception of river dynamics and, more generally, changing ideas about 'nature' (in particular about the 'nature' of disease) played an important role. Elites were at the forefront of such changes and could have a pivotal effect, such as the wealthy merchant elite had in the case of Lyon (Reynard 2016).

Pre-industrial cities often grew only on one bank of the river. Rivers and their catchments as elements structuring the territorial organization, often as administrative boundaries, played an important role in the spatial reach of changes. Administrative boundaries, once established, had repercussions for economic development and, to some extent, demography. While controlling demography was all but impossible in the nineteenth century, managing it became an important task bearing on the transformation. Industrialization itself was a formidable driver of the transformation. Two factors are particularly important.

One is a revolution in the knowledge on which engineered artefacts were based. Science became not only the idiom of the discourse, as Christopher Hamlin has aptly argued (Hamlin 1990), but also material artefacts were now constructed differently. Haphazard, experience-driven craft-based technical development gave way to the entangled science and techniques-based complex of technology. With this, the dominant use of rivers and other aquatic resources changed profoundly, as did the range of (main) users of the rivers and changes.

The other important factor is the change of the energy source. The shift from wood to coal and from kinetic to heat energy had far-reaching implications for urban metabolism. It led to a dramatic change in city-hinterland relations, intensified by the new transportation network of the railway. One of the most important influences on the use of the aquatic networks was the development of railways. With growing specialization in all occupations, city planning professionalized. The internationally connected experts used models from pioneer cities, so innovations in one city could easily become the model for others. Spatial organization and spatial development changed in accord with the transformations in production and its underlying energy provision, a shift that could be called the spatial dimension of modernization. Uses were increasingly segregated and with them, the 
functions of aquatic and other resources became more monofunctional. This would play out differently at the small, local scale in each city, but everywhere, urbanites had to deal with legacies of prior uses offering city planners yet another possibility to show their growing expertise. Some of the arrangements would persist and influence the further development profoundly. In all cases of urban modernization, hygienic concerns were a major driver of transformation. Cholera was not only decisive in city planning; it brought medical expertise to the forefront and with it, changing ideas of these professionals about nature. Cities were transformed with the change from miasmatic theory to bacteriology.

The impetus for change came from resource scarcity, population growth, or the necessities of dealing with vulnerable systems increasingly under pressure due to overexploitation. In all four cities, a relative lack of water caused by increasing demand required new ways and sources of supply often far from the cities. Water scarcity in rivers and brooks was intensified by increasing release of nutrients well above absorption capacities of the aquatic ecosystems. New toxins emitted by the growing chemical industry, intensified pollution. The specific sets of drivers chosen and evolving in each of the four cities demonstrate that in the closely interlinked urban-river system one could pull different strings but, in all cases, the result would be similar. Urbanites, however, perceived their actions as specific.

The theme of this paper is how similar the cities have become, which important differences characterized their transformation, how that transformation affected watercourses and, in turn, how watercourses affected the transformation.

The studies of the four cities included in this thematic issue of Water History elucidate these trajectories, focusing on the particular driving forces in each case. Brussels and the Senne are discussed by Chloé Deligne; Lyon and the Rhône by Pierre-Claude Reynard, the Isar and the many creeks derived from its waters in the city of Munich are treated in the article by Winiwarter et al. (2016). A large grant from the Austrian Science Foundation (FWF P 25796-G18) allowed for an interdisciplinary in-depth study of Vienna with an emphasis not only on the dominating Danube River, but also on a major tributary, the Wien River, and the role it played for the industrial development of Vienna (Pollack et al. 2016). The question of persistence of older patterns of water use in the urban fabric drove the investigation by Friedrich Hauer et al. (2016).

\section{Urban-river-systems and their transformation from an environmental viewpoint}

Within environmental history, the investigation of river-society-relations has become a prominent field (see e.g., Mauch and Zeller 2008). Large river systems have received particular attention. Narratives have evolved from being either 'histories of the dead river' (e.g., Fradkin 1981; Hill 1997) or 'histories of the conquered river' (e.g., Worster 1992; Tvedt and Jakobsson 2006) to more complex treatments of the interaction between rivers and societies. Their narratives also include rivers as actor (White 1995; Cioc 2002; Pritchard 2011).

Urban rivers in European cities have been addressed in overview articles (e.g., Schott and Toyka-Seid 2008), but long-term studies are scarce. The long-term interdependency of hydrographically induced technological change and urban development has been discussed in an early study by André Guillerme about 18 cities in Northern France between 300 and 1800 A.D. (Guillerme 1988). Schott (2007) conceptualized both the impacts of a city on its 
river and vice versa. Castonguay and Evenden (2012) provide an overview of current debates and approaches to urban rivers. London and the Thames is the best-researched major European city. Porter (1998) describes the entanglement of political, economic, and social forces in creating arrangements (see also Hamlin 1990; Keene 2012). European urban metabolism studies have centered on Paris (Barles 2007; Billen et al. 2012) but are also available for North America (Keeling 2004, 2005). Hoffmann $(2007,2010)$ provides a metabolic approach to European medieval cities. Studies using the concept of social metabolism investigate the flow and transformation of material resources and energy into, within, and out of social systems and describe the changes of these flows through time. Rivers play a role especially as routes of transport connecting, for example, cities and their hinterland or as recipients of waste (e.g., Gingrich et al. 2012; Barles 2007).

Few investigations explicitly consider the spatial distribution of river functions and uses. One example is Backouche's $(2000,2008)$ comprehensive study about Paris and the Seine from the middle of the eighteenth to the middle of the nineteenth centuries. She focuses in particular on the modified appearance and perception of the riverbanks during a first phase of industrialization. A GIS-based (geographic information system) study of long-term hydromorphological changes is available for the Danube River in Vienna between 1500 and 1900. Numerous historical sources, above all maps, were used for the pioneering regressive-iterative reconstruction (Hohensinner et al. 2008, 2013).

The history of rivers in urban areas is closely linked to the history of water supply and waste water discharge. Winiwarter (2000) has looked at sewage systems as colonizing interventions into the natural water cycle, taking surface sealing and groundwater extraction into account. She draws attention to the side effects of using the potential energy stored in water for energy generation, which inevitably leads to morphological changes of natural watercourses. Environmental history has added an important focus on the development of urban infrastructures of provision and disposal (Tarr and Dupuy 1988; Barles 2007). Prominent studies focus on changing technical infrastructures of provision and disposal, as well as perception of problems connected to these changes (Tarr 1996; Melosi 2000). In recent years, studies of past wastewater disposal and pollution of rivers studied from an urban metabolism perspective have gained importance. Tarr (2005) and especially Barles (2007), for example, demonstrated how the output of nutrients increased due to urban population growth and how sewage systems as new types of discharge changed in combination with the release of nutrients into rivers from new types of fertilizers.

A multitude of environmental history studies focus on the supply of water for cities. Water supply and waste water discharge are often analysed in combination (Tarr 2002; Goddard 2005; Barles 2007). Publications on problems related to contaminated drinking water and sanitation discourses in industrializing cities (Anderson 1988; Juuti et al. 2007; Rautanen et al. 2010) are numerous. Others focus on the power relations regulating access to water (Kahrl 1982; Otero et al. 2011). Tello and Ostos (2012) recently published a study on the environmental imprint of urban water consumption in long-term perspective.

In the nineteenth century, a transformation started in England and spread first in the northern hemisphere but would soon have worldwide repercussions. This transformation, the Industrial Revolution, has been the object of much scholarship. Building on an earlier conceptual paper (Winiwarter 2000) we explore its links to urbanization and the multifacetted complex called modernization from an environmental history viewpoint.

Stefania Barca showed in a review article on energy, property, and the Industrial Revolution narrative, how environmental historians have pioneered studying the Industrial Revolution with adequate attention to the fact that 'the economy' is a subset of ecological systems and its development best understood in co-evolutionary terms (Barca 2010). 
According to her, three U.S. historians have to be credited with developing this narrative. In T. Steinberg's landmark study on the industrial transformation of New England, industrial capitalism is understood as a set of ecological relations as much as an economic state of affairs (Steinberg 1991). Steinberg studied industrial development along the Merrimack River. He thus followed an earlier pioneering study by Donald Worster who had concentrated on water and power in the American West as early as 1985. Both cases show that in the co-evolutionary transformation, legal and cultural norms proved to be as fluid as the water that drove industrialization.

The developments have become possible through water engineers providing more and more sophisticated technology and because markets allowed a certain kind of effective demand to become a driving force for innovations in supply. For Steinberg, urbanization is a symptom and outcome of industrialization. Reshaping the Merrimack Valley to fit "the needs of large scale textile production" (77) meant changing rural into urban and to turning water into power and production. Steinberg follows the massive conflicts and discusses the demise of fisheries and the deterioration of health linked to urbanization/industrialization, which arose from massively increased water pollution. Rural did not simply become urban everywhere, but the rural sphere was influenced by urban developments (Barca 2010). Similarly, but focusing on commodity flows, William Cronon has shown the transformative change in the countryside brought about by the city's industrialization and the networks it created, be it railways or canals for Chicago (Cronon 1991).

In 1995, Richard White took the study of the role of rivers for human society further by creating his narrative with a focus on work (White 1995). He conceptualized the Columbia River not just as an energy carrier, but saw the agency of the river interacting in inextricable ways with human agency through work on the part of humans and also on the part of the river.

Several historians have drawn close connections between hydraulic energy use, early modern economic growth (Ciriacono 2006), industrialization (Steinberg 1991), or high modernism (Evenden 2004). Gandy (2006) points to the cultural aspects of urban water supply and discharge and the hygiene discourse of the nineteenth century, especially accentuating its connection to new forms of discipline and privacy. French authors highlighted the higher and higher levels of technical specialization and capital investments required by mineral energy sources. Energy became a matter for investors, scientists, and engineers. Eventually, energy provision would emerge as an independent and autonomous sector that would play a decisive role in regulating the new economy.

Energy sources have effects on all areas of social interaction, but also on the biophysical basis of society. To conceive of the material interaction patterns of society as a societal metabolism with an input- and output-interface to the environment has led to an understanding of the Industrial Revolution as a decoupling process. The direct coupling of energy and land via biomass (e.g., wood) was severed. This freed human labor from working the land, but labor was needed more and more for the extraction of fossil energy carriers. This has caused a shift in society's energy strategy away from tapping into flows of renewable energy towards the exploitation of large, but, nevertheless, finite stocks of fossil energy (Krausmann et al. 2008, p. 188; quoted in Barca 2010).

Without explicitly alluding to it, Krausmann et al. (2008) make a case for the importance of changes in infrastructure when they discuss changes in metabolism. Such an emphasis is shared in culturalist approaches, in which infrastructure has been identified as driver of modernization: 'Building infrastructures has been constitutive of the modern condition, in almost every conceivable sense. At the same time, ideologies and discourses of modernism have helped define the purposes, goals, and characteristics of those 
infrastructures. In other words, the co-construction of technology and modernity can be seen with exceptional clarity in the case of infrastructure. (Edwards 2003) Hydraulic infrastructures and their place and role in the naturally different riverine ecosystems of four European cities during the process of changing the energetic basis of society are the focus of the studies in this issue (Deligne 2016; Hauer et al. 2016; Pollack et al. 2016; Reynard 2016; Winiwarter et al. 2016)

For the United States of America, industrialization along the Merrimack River meant converting rural into urban space. However, Europe had been urbanized to some degree since the twelfth century and the cities we are comparing here all have a long history, predating the advent of the Industrial Revolution by centuries. Here, modernization and the Industrial Revolution at large meant a wide- and far-reaching intervention into existing (infra-) structures, an intervention, we argue, with consequences in particular for the relation between cities and their rivers.

\section{What drove the transformation in urban-river relations?}

Urban and environmental historians have sought to understand the transformation of cities and identified important features in different periods. Eminent urban historian Penelope J. Corfield recently summarized the main factors discussed by the historical community to explain city-building and economic modernization (Corfield 2013). Trade, production, population, and state building are featured in the literature, but the approaches differ with regard to the relative impacts of these factors on urban development and on the transition from agrarian to industrial society. While Corfield does not explicitly mention environmental factors, she does integrate material interactions into her discussion: 'Once established, all towns and cities have common requirements. They need sustainable resources (including water, food, raw materials, and, integral to growth, a stream of population recruits), plus a viable economic role (including the economic functions of administrative and religious centers [...]). Urban viability also depends upon a complementary rural support system linked by commercial networks. Trade, in turn, needs political/societal security to operate successfully. Towns also require a modicum of organization to sustain settled populations living in compact areas at relatively high densities.' (Corfield 2013, p. 828).

The industrializing city also has come to be understood as the laboratory to forge new ideas about disciplining life through space, as John Pløger recently re-iterated (Pløger 2008). The hygienic requirements of the densely populated urban spaces were a welcome basis for disciplinarian interventions. 'It was through the city that societies developed ideas about how to discipline life through space. This recognition in part followed medical experiences with uncontrollable diseases threatening cities. Governments discovered that forms of bio-politics-building on techniques of surveillance, registration, classification, division of inhabitants, and, if necessary, exclusion from space-made it possible to control the spread of diseases. European cities were then constructed according to the same principles or ways of thinking, most notably seen in the great hygiene projects from the 1820s in France and in Scandinavia from about 1880 to 1930. Through cities, architects and planners recognized the social power of space and especially its normalization forces. [...] The city became a laboratory for the emergent disciplinarian society, which Deleuze calls “the society of control” (Deleuze 1995).' (quoted after Pløger 2008, p. 52). 
Environmental historians would not deny this connection, but they emphasize other questions, namely the role particular nature(s) played and how resistant these nature(s), including human nature, were to disciplinarian interventions. Their material creationsfirst and foremost infrastructure-would, over time, add to the repertoire of material resistances urbanites faced in the modernized city. However, one should not forget the dialectical status of infrastructures (Edwards 2003).

It is clear that materiality poses problems for urban organization, which are met with physical and cultural interventions. Infrastructure becomes the key issue for those scholars interested in the integration of nature and materiality in studies of urban history. For this involvement of materiality, conceptual terms have been developed starting from a basic difference (city-nature, society-technology). The relationship of the parts is addressed either as unilateral relationship or as interaction. The material part is conceived as socially constructed, the ideational analyzed as determined by the material. To integrate these perspectives and balance the unilateral models, concepts of interaction, such as co-construction or co-evolution, are used.

T.J. Misa and co-authors offer co-construction as an interaction-based concept of modernity being driven by technology and vice versa. While modernity theory misses what is modern about technology, technology studies fail to relate their empirical findings to an abstract level and to make far-reaching interpretations about modernity. Misa's work combines the' technological shaping of society' with the' social construction of technology' by adopting the notion of co-construction (Misa et al. 2003). But without a clearer idea about the driving forces of infrastructure development, the explanation that modernization was linked to it remains a black box. Environmental historians can try to open it by paying attention to the difference that natural conditions made.

\section{A diversity of socio-natural sites: four European cities and their river networks in the nineteenth century}

Brussels, Lyon, Munich, and Vienna and their river networks have been chosen to study how industrialization and modernization shaped urban rivers. The four cities differed in size and population as well as in their political and administrative roles. Size and dynamics of their surface waters also was very diverse. The changes of their water networks, especially during the nineteenth century, allow the study of the role and effects of aquatic environments in the urban transformation, as debates and concerns about the hydrographic features of the above- and below-ground water in cities were a crucial part of modernization.

\section{Different sizes and dynamics of urban rivers}

Urban populations had managed rivers for centuries for their specific needs, often in similar ways across Europe. How urban rivers could be integrated into the local economy and the urban fabric depended on natural characteristics and dynamics. The rivers and streams of the four cities reflect some of the diversity of natural and artificial waters in Europe's cities. Local actors resorted to different practices and arrangements when dealing with alpine and montane running waters with their inherent fluvial dynamic as compared with those along gently flowing lowland streams (Winiwarter and Schmid 2008). The Upper Danube-besides the Upper Rhine, the largest alpine river in Europe, characterized 
by numerous heavy floods caused by rainfall, snowmelt, or ice jams, posed challenges to the Viennese, especially with regard to interventions into the river regime. The Rhône in Lyon and the Isar in Munich are both characterized by an alpine flow regime, but are smaller than the Danube. Prior to channelization in the nineteenth century, they flowed in braided channels and deposited extensive gravel bars. The Isar is an order of magnitude smaller than the Danube. Consequently, it was easier for urbanites to create more persistent arrangements, such as the elaborate millstream system along this river in Munich. It was not until the mid-nineteenth century that the Rhône and the Isar were finally channelized. The Viennese Danube followed later, its thorough regulation was accomplished between 1870 and 1875.

Wien River and Währing Creek are montane tributaries of the Viennese Danube, much smaller than the Isar or the Rhône. Due to the impermeable sandstone layers of its catchment, the Wien River exhibited regular heavy floods, often causing tremendous damage, while Währing Creek produced only local impacts. Its course features the highest channel slope amongst the studied water bodies, but with a peak flow of ca. $9 \mathrm{~m}^{3} \mathrm{~s}^{-1}$, it is also the smallest.

Brussel's Senne featured a different history, not only due to its physical characteristics, but also because of its early and intensive human transformation. As a small sinuous, partly meandering, lowland river, it could be easily integrated within the fabric of the medieval town. Between 1550 and 1561, the navigable Canal de Willebroek was constructed between Brussels and the rivers Rupel and Scheldt. A part of the Senne's discharge was diverted to the head of the canal, significantly affecting the hydromorphology of the river.

The hydrologic impact of urban canals could take place outside the city. The Wiener Neustadt Shipping Canal in Vienna is a case in point. This artificial canal was excavated around 1800 to improve transportation to the center of Vienna. The major challenge was to provide it with a sufficient water supply, which came from streams close to the canal's headwaters, approximately $40 \mathrm{~km}$ south of Vienna in another catchment.

Each of the studied water bodies provides distinct physical characteristics that facilitated or restricted certain human uses at different times. Besides socio-economic drivers, the nature of these water bodies is a crucial factor to understand pathways of urban development.

In Fig. 2, we provide an overview of the hydromorphological characteristics of surface waters in the four cities, including the Wiener Neustadt Shipping Canal for comparison. Figure 2 also provides a short description of regulations and describes the relative position of the city within the catchment including the distance to the sea. Any urban environmental history has to take this kind of characteristics into account.

\section{General trends visible in the urban layout}

Population grew considerably in all four cities, especially in the second half of the nineteenth century. Vienna was a magnitude larger and population growth clearly outpaced that of the other cities (see Fig. 3). But in all cases, population growth resulted in overexploitation of existing infrastructures and urban territory and in subsequent resource scarcity, visible, for instance, in the demand for building areas, a pressure experienced in all cities.

Figure 4 compares urban expansion and surface waters around 1800 and 1900. Vienna and Munich were originally located on one bank of their main rivers, Danube and Isar. Several natural small streams flowed aboveground in Vienna around 1800, while in Munich, semi-artificial canals of the Isar formed a complex aquatic network to serve the 


\begin{tabular}{|c|c|c|c|c|c|c|c|}
\hline Characteristics & $\begin{array}{c}\begin{array}{c}\text { Senne } \\
\text { (Brussels) }\end{array} \\
\end{array}$ & $\begin{array}{l}\text { Rhône } \\
\text { (Lyon) }\end{array}$ & $\begin{array}{c}\text { Isar } \\
\text { (Munich) }\end{array}$ & $\begin{array}{l}\text { Danube } \\
\text { (Vienna) } \\
\end{array}$ & $\begin{array}{c}\text { Wien River } \\
\text { (Vienna) }\end{array}$ & $\begin{array}{c}\text { Währing Creek } \\
\text { (Vienna) }\end{array}$ & $\begin{array}{l}\text { Wr. Neustadt } \\
\text { Canal (Vienna) }\end{array}$ \\
\hline river type & lowland & alpine & alpine & $\begin{array}{c}\text { alpine- } \\
\text { mountainous }\end{array}$ & mountainous & mountainous & artificial lowland \\
\hline channel pattern & $\begin{array}{c}\text { sinuous/ } \\
\text { meandering }\end{array}$ & braided & braided & anabranched & sinuous/braided & straight/sinuos & straight \\
\hline length of river $(\mathbf{k m})$ & 103 & 812 & 295 & 2860 & 34 & 5 & 63 \\
\hline location upstream estuary $/$ mouth $(\mathrm{km})^{1}$ & 36 & 325 & 148 & 1929 & $15-0$ & $0-5$ & $0-5$ \\
\hline catchment area total $\left(\mathrm{km}^{2}\right)$ & 1160 & 98500 & 8370 & 817000 & 230 & 5,1 & - \\
\hline catchment area upstream $\left(\mathrm{km}^{2}\right)$ & 830 & 50500 & 2810 & 101700 & 230 & 5,1 & - \\
\hline catchment area upstream (\%) & 72 & 51 & 34 & 12 & 100 & 100 & - \\
\hline average discharge $\left(\mathrm{m}^{3} / \mathrm{s}\right)$ & 5 & $1030^{5}$ & 64 & 1910 & 1.3 & $0.04^{4}$ & $1-1.5$ \\
\hline$\Delta$ min-max discharge $\left(\mathrm{m}^{3} / \mathrm{s}\right)^{2}$ & 95 & $3950^{5}$ & 1034 & 9540 & 320 & 9.4 & - \\
\hline main flood season & summer & spring/summer & $\begin{array}{c}\text { late spring/ } \\
\text { summer }\end{array}$ & spring/summer & summer & summer & - \\
\hline type of floods & rain & $\begin{array}{c}\text { rain/snow } \\
\text { melt/ice jams }\end{array}$ & $\begin{array}{c}\text { rain/snow } \\
\text { melt/ice jams }\end{array}$ & $\begin{array}{c}\text { rain/snow } \\
\text { melt/ice jams }\end{array}$ & rain/snow melt & rain & - \\
\hline probability of freezing over year ${ }^{3}$ & very rare & rare & very rare & every $2-3$ years & every year & every year & every year \\
\hline channel slope (\%) & 0.6 & 0.8 & 2.4 & 0.4 & 4.4 & 26 & 1.6 \\
\hline type of sediments & sand/silt & gravel/sand/silt & gravel/sand/silt & gravel/sand/silt & gravel/sand & gravel/sand & sand/silt \\
\hline fluvial dynamics & low & high & high & high & high & moderate & very low \\
\hline history of river regulation & $\begin{array}{c}\text { intensive since } \\
\text { Middle Ages, } \\
\text { navigable canal in } \\
1551-1561 \\
\text { complete } 1866- \\
1872 \\
\end{array}$ & $\begin{array}{c}\text { major works in } \\
1770 \text { s, complete } \\
1857-1863\end{array}$ & $\begin{array}{c}\text { complete } 1854- \\
1895\end{array}$ & $\begin{array}{c}\text { intensive since } \\
1830, \text { complete } \\
1870-1875\end{array}$ & $\begin{array}{c}\text { intensive since } \\
1814 \text {, complete } \\
1895-1906\end{array}$ & $\begin{array}{c}\text { intensive since } \\
1848, \text { complete } \\
1891-1901\end{array}$ & $\begin{array}{c}\text { built } 1797-1803, \\
\text { shut down in } \\
\text { Vienna } 1930\end{array}$ \\
\hline use of potable water & no & yes & no & little & no & no & no \\
\hline
\end{tabular}

Fig. 2 Selected characteristics of the surface waters of the four cities

Explanations for Fig. 2: 1 river km upstream from the estuary, 2 difference between annual low flow and the 100-year flood magnitude, 3 rough estimation, 4 theoretically (creek is part of sewage system today), 5 excluding tributary Saône that meets the Rhône downstream from the historical city centre; average discharge including Saône $=1475 \mathrm{~m}^{3} \mathrm{~s}^{-1} ; \Delta \min -\max$ discharge $\left(\mathrm{m}^{3} \mathrm{~s}^{-1}\right)=5620 \mathrm{~m}^{3} \mathrm{~s}^{-1}$

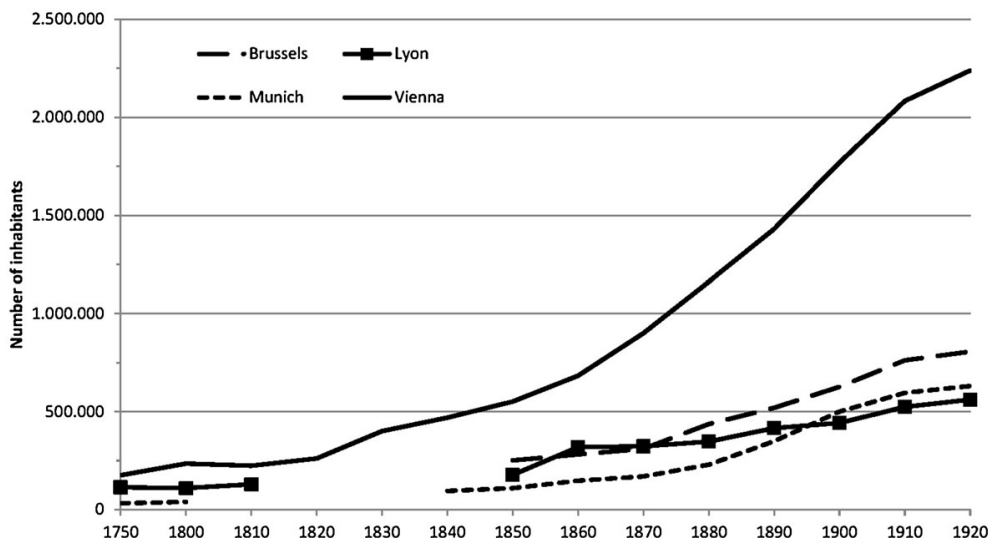

Fig. 3 Population growth in the four cities from the late eighteenth to the beginning of the twentieth century Source: www.populstat.info; graphic by authors

city's demand for water. Brussels exhibits a picture similar to Munich, albeit including a major shipping canal and several fishponds. Lyon's city center had developed on the banks of the Saône and expanded after the late Middle Ages towards the peninsula upstream of the confluence of the two urban rivers: Rhône and Saône. No small tributaries served the city's demand for water or wastewater discharge and energy supply. But the city's location in the alluvial bed of the large rivers allowed the sinking of groundwater wells (Reynard 2016).

Around 1900, the situation differed remarkably from that of 1800 . The cities had grown noticeably and crossed the banks of their main rivers. Areas in the inundation-prone floodplains that had remained almost untouched were now densely populated in all four 
cities. Urban planners of the late nineteenth century could already rely on industrial technologies of bridge building and flood protection and hence, the rivers no longer impeded development. The main rivers were channelized and dikes along the banks protected people from floods. Consequential hydromorphological alteration by bank alignment and straightening of - in part-artificially built channels characterize the nineteenth century interventions in the four cities, if to a different degree. In Lyon, the number of bridges is particularly striking, owing to the growth and increasing integration of the left bank. The

\section{a}

\section{VIENNA}

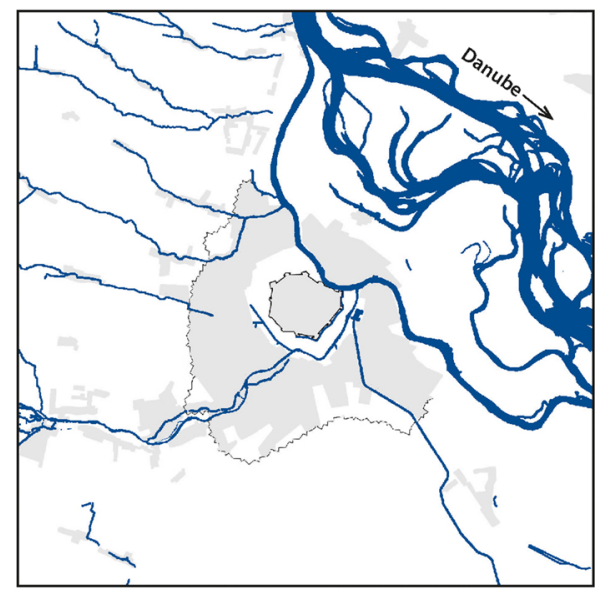

1825
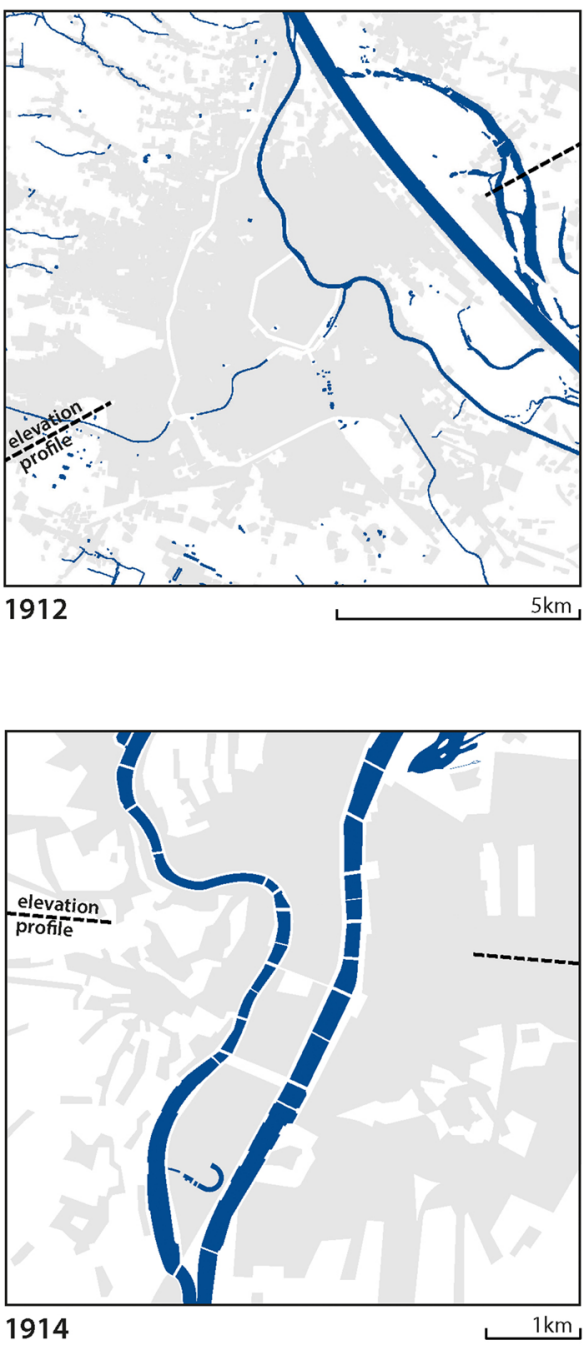

\section{LYON}

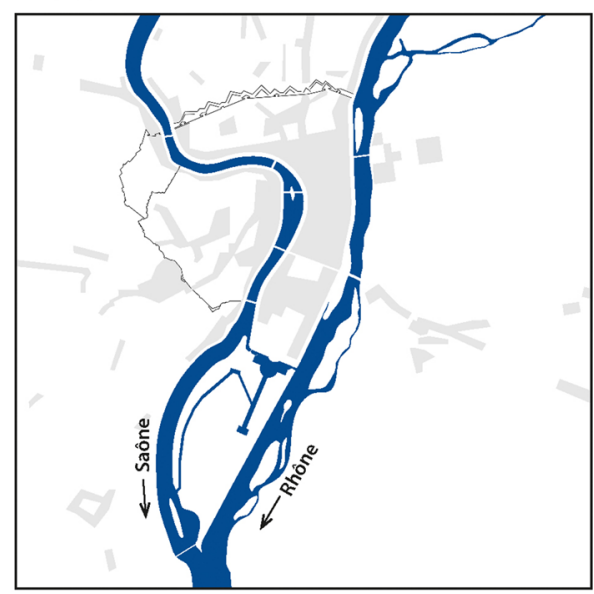

Fig. 4 Ground plots of Vienna and Lyon (a), Munich and Brussels (b) and their surface waters around 1800 (left column) and around 1900 (right column)

Source: Original work by Friedrich Hauer on the basis of topographical maps and existing reconstructions; Location of cross-section of elevation profiles in Fig. 5 indicated with dashed lines 
b

\section{MUNICH}

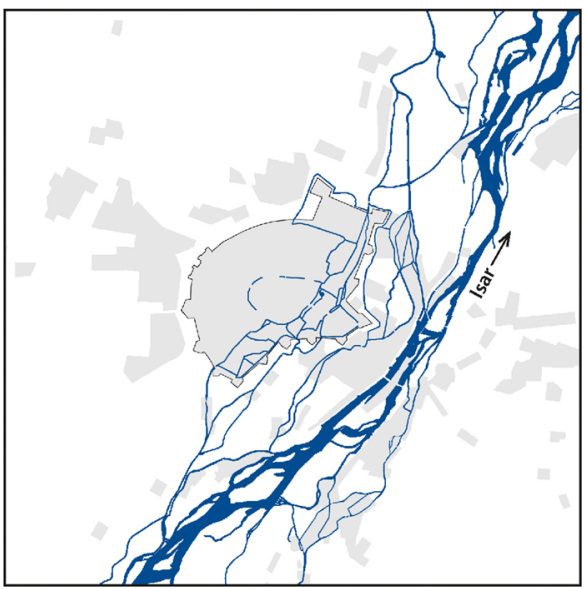

1802

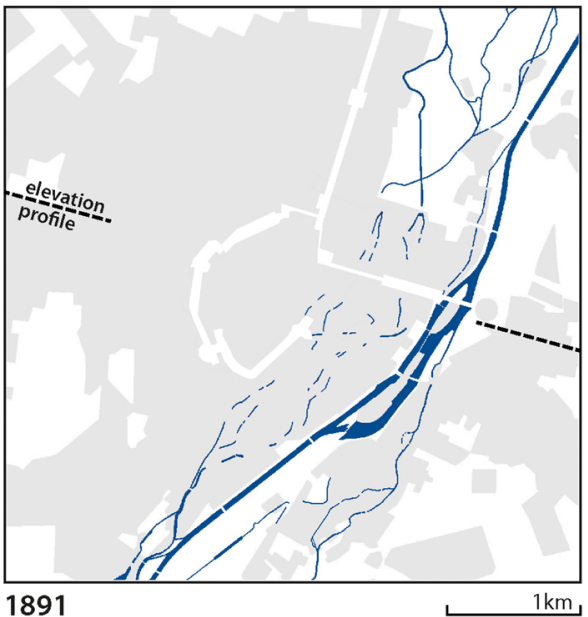

\section{BRUSSELS}
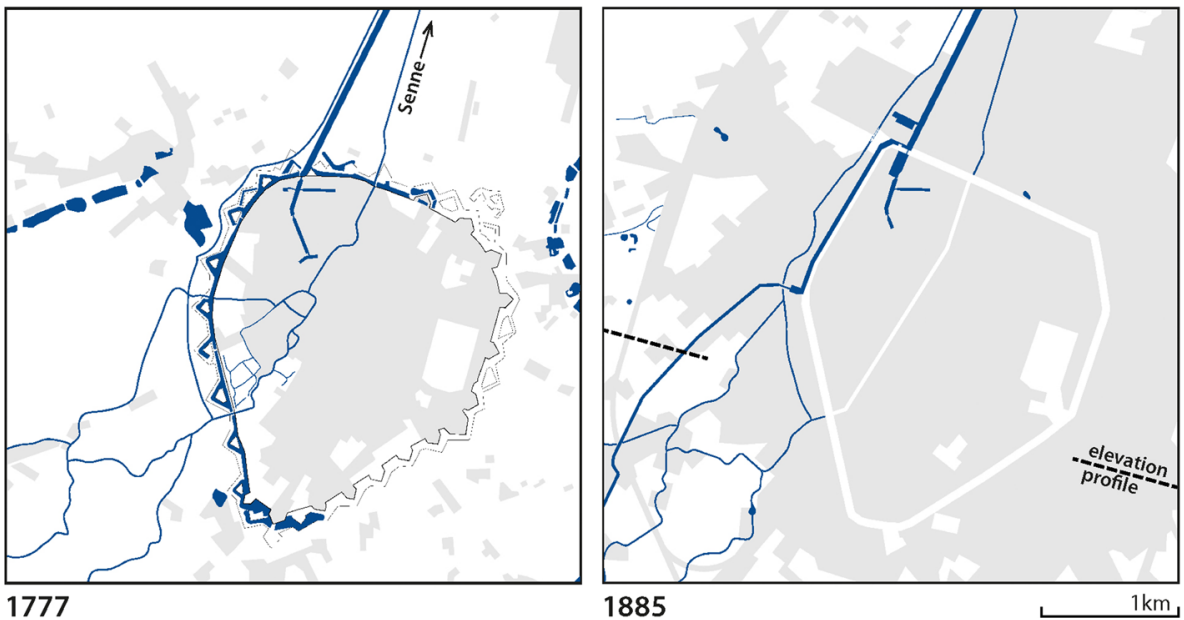

Fig. 4 continued

most striking feature immediately visible by comparison, as presented in Fig. 4, is the all but complete disappearance of the Senne and of urban tributaries of Danube and Isar. Instead, a complex network of water pipelines - often supplied from distant springs - and sewers had been constructed belowground, invisible on the topographic maps. In the following subchapters, we will discuss the pathways leading to this similarity in more detail.

Figure 5 shows the topography of the cities in cross profiles with the location of the historical centers marked in grey. The comparison highlights differences in the topographical endowments and developments. In all investigated cities, the main river was a barrier of urban growth until the nineteenth century. However, in Vienna and to a lesser 


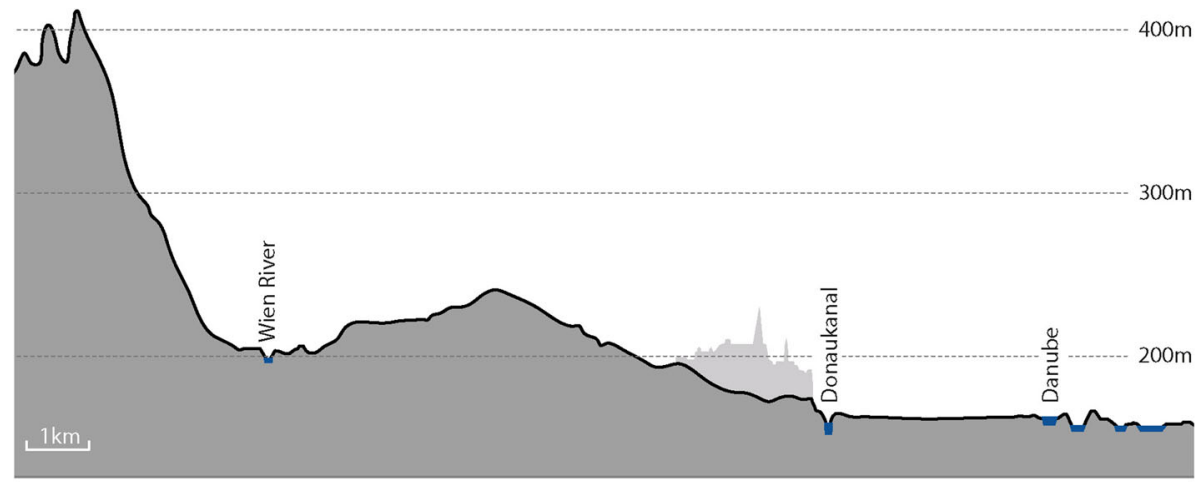

\section{VIENNA}

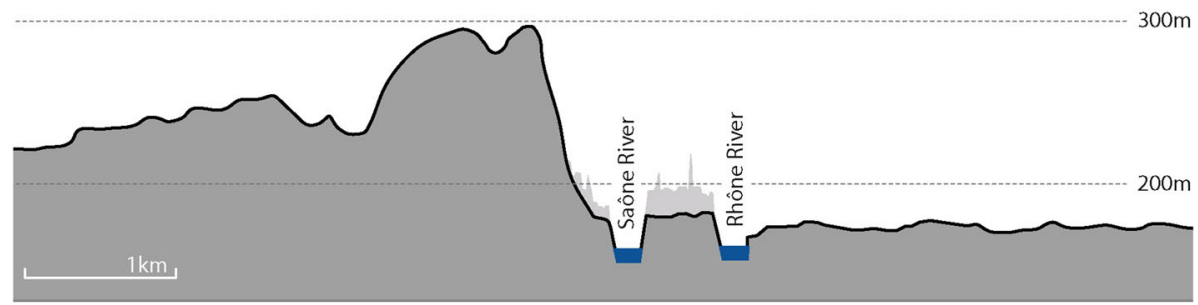

\section{LYON}

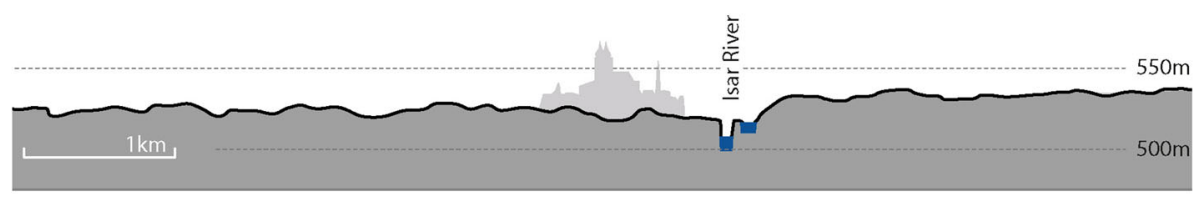

\section{MUNICH}

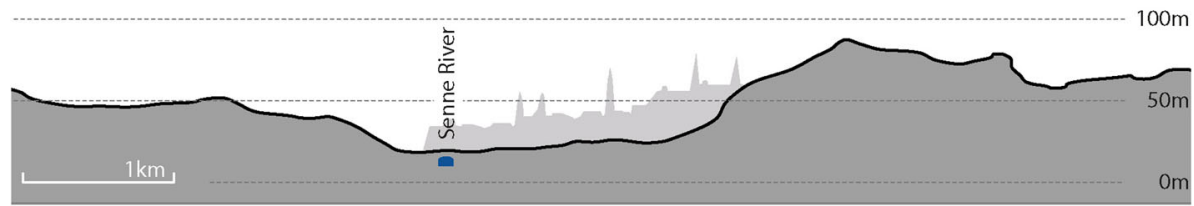

\section{BRUSSELS}

Fig. 5 Schematic elevation profiles of the four cities. Schemes are based on present-day topography, indicating above-sea-level altitudes, main water courses and the approximate situation of the historic city centers. Section lines are displayed in plot plans in Fig. 4. Basis: European Digital Elevation Model (EUDEM, European Environment Agency) 
degree in Brussels, hilly areas were an additional obstacle for the growth of densely populated urban areas. The inhabitants of Lyon avoided settling along the dynamic Rhône until the $18^{\text {th }}$ century, but the right-hand banks of the Saone were early centers of urban development despite the hills rising next to the river. In the nineteenth century, especially in Vienna and Lyon, the hilly areas were the location of mansions of wealthy people. In contrast, the former floodplains of the Danube and the Rhône, now protected by dikes, became densely populated.

\section{Vienna and the Danube, the Wien river and the Wienerwald creeks}

A thorough study of the Danube and Vienna, one of the cities built along its shores, previously published in this journal (Gierlinger et al. 2013; Haidvogl et al. 2013; Hohensinner et al. 2013) made clear that Vienna's development was closely tied to urban waters, to streams and rivers, to groundwater, and to human-made canals and sewers.

As Hauer et al. (2016) and Pollack et al. (2016) can show in unprecedented spatially explicit detail, the above- and belowground aquatic network had a large bearing on urban development. At the beginning of the nineteenth century, water use was multifunctional. Functions encompassed transportation and energy delivery for grain mills and process water for various crafts such as fullers or dye producers. Groundwater and the waters channeled from the headwaters of the small creeks of the Wienerwald also served as drinking water. Watercourses had long been a productive habitat whose biomass production (fishes and invertebrates alike) was of importance. The Danube floodplains featured water meadows and riparian forests, which were important for fodder and wood production and as hunting grounds for the nobility. In the course of city development, the waterfront became a prime space for building, resulting in new users with new interests. Water was also used in representative contexts to power fountains and other decorative waterworks (Winiwarter et al. 2013).

Between the seventeenth and early twentieth centuries, Vienna changed from a premodern fortified seat of the imperial court to the industrialized capital of a by then much smaller territory. The most dynamic phase of urban growth lies between 1850 and 1918 (Weigl 2000). In this period, Vienna's population increased almost by a factor of five from about 500,000 to more than two million inhabitants, about 15 percent more than today. Vienna evolved at the banks of the extremely dynamic Danube upper reach with smaller or larger floods occurring at almost any season. Urban tributaries also showed high hydrological dynamics (see Figs. 1, 2, above). Low water could be as problematic as floods. Pollution of surface and groundwaters increased in the course of industrialization. After the first cholera epidemic in 1831, centralized sewage canals were built and expanded in the following decades. However, the speed of constructing new pipes never kept pace with population growth and, in combination with excessive pollution, pre-industrial water supply systems from local sources reached their limit. This over-exploitation of the resource base (cp. Fig. 2, above) brought the patchwork phase of urban infrastructure building to a close.

The layout and construction of water mains, a major engineering feat, converted distant alpine catchments and their springs into the main source for clean drinking and process water after 1873. Energy supply from local mills was no longer needed after the shift to steam power. This eased the multiple demands laid on the small Viennese Danube tributaries during the pre-industrial phase. The small watercourses' main function now was that of open sewers, where fish and other aquatic animals were thus much diminished. Marine fish import, possible by railways, had started in 1899. Therefore, demand for local 
fish stalled (Jungwirth et al. 2014). While the channelized Danube kept its role for transport, the small tributaries lost their economic importance. Only their role as waste and wastewater recipients remained, leading to their integration into the underground sewage system. By the end of the nineteenth century, they had been vaulted, their waters were now solely needed to flush sewage downhill.

\section{Munich and the Isar}

Like the Danube, the Rhône or the Senne and their tributaries, the Isar, its small side arms and numerous artificial channels, respectively, served many needs of Munich and its urban development. Like Vienna, Lyon or Brussels, Munich was built on one bank of the town's main river. But as no natural tributaries existed, a complex network of artificial canals was dug and gradually improved between the thirteenth and eighteenth centuries. Both the Isar and the artificial waters served shipping and milling of various products. They supplied different crafts with process water; they provided gardeners, launderers, and the moat around the fortification walls. They were the recipient of waste and wastewater. The Isar and the Viennese Danube both show a high fluvial dynamic. The span between mean and maximum discharge and the slope of the Isar are even higher (see Fig. 2). This uneven flow of the Isar also prompted the network of artificial canals as it precluded most direct commercial uses except log driving and rafting. Diversion of Isar water into small ditches had started as early as the thirteenth century, creating the hybrid urban surface water network depicted in Fig. 4. As the city is located on a relatively flat stretch of the alluvial plain of the Isar, the topography made channel-building easier than in Vienna (see Fig. 5). The Isar was an administrative boundary until 1854. This had an important bearing on city development (Winiwarter et al. 2016), much like the Rhône divided Lyon and its left-bank neighbor La Guillotière until 1852, when they were united by a Napoleonic decree (Reynard 2016).

Munich had a much less turbulent political history compared to Lyon. It was the capital of a small duchy and, after 1806, of the Bavarian kingdom. Conflicting interests of the duke and king, respectively, and the urban government nevertheless affected waters and water use. Population growth was modest compared to the large European metropolises, although relative population growth on the territory of the medieval and early modern city was considerable: The urban population amounted to 33,000 people at the end of the eighteenth century; it tripled to about 100,000 by 1850 and quintupled to almost 500,000 around 1900.

Water pipelines and simple, patch-worked sewers were built in Munich already in the sixteenth century and extended and improved several times thereafter. In the nineteenth century, the three cholera outbreaks in 1836, 1854, and especially in 1873 necessitated a new drinking water supply system, a sewage network, and waste disposal. Fear of cholera was the great whip that drove sewage and water provision projects, as German historian Thomas Nipperdey put it. Max von Pettenkofer, the famous physician and epidemiologist, played an important role in the construction of this sewage system. Pettenkofer studied the causes of cholera. Despite assuming that it was created by emanations from unhealthy soil, a theory that would later prove to be wrong, he drew a connection between tainted water, soils, and air and the cholera outbreaks (Pettenkofer 1855; Nipperdey 1990). The large sewage network built between 1862 and 1875 was only a partial success, because conduits frequently clogged if not properly cleaned. In 1881, work on a better system started. With the opening of the new drinking water pipeline from the Mangfall River in 1885, Munich shifted soon after also to using distant water supply sources. 
Debates about vaulting surface waters had started in the 1840 s, but their importance for process water supply, hydropower production and as receivers for waste and wastewater delayed or at least decelerated efforts. In 1869, almost one-third of waters was already vaulted, covered with buildings or made otherwise inaccessible. The need to use local waters for producing energy vanished with the construction of new and more efficient electric hydropower plants and long-distance transmission infrastructure (1894/95: Muffatwerk and Maximilianswerk). The changed role of surface waters becomes visible in Munich also when looking at their fate as transport routes: In 1898, it was decided to build the long debated and desired new harbor for the large number of rafts arriving in Munich from upstream. But when this harbor was finished, rafts were about to give way to railways as the main means of transportation. Lumber transport was gradually taken over by railway and the infrastructure for wood removal from the water, the grill, was removed and the Holzgarten storage area and the log-driving canal were filled.

Railways, the new hydropower plants together with the water pipeline from Mangfall and the sewage network made the city definitely independent from their local water resources. In contrast to Vienna, Munich's urban development was largely based on artificial canals. They could easily be integrated to the sewer network without paying attention to natural flow dynamics and could be filled in just as easily. But the construction of the new harbor as an expensive waterborne infrastructure when such infrastructure was about to become obsolete provides an interesting parallel to the Wiener Neustadt Shipping Canal in Vienna (Hauer et al. 2016).

\section{Lyon and the Rhône}

Lyon grew at the confluence of two great yet very different rivers: the slowly flowing Saône and the very dynamic Rhône, which evolved as the main urban river in the nineteenth and twentieth centuries (see Figs. 4, 5). During frequent periods of low water, the Rhône could shrink to shallow and foul pools. Its banks were then quarried and sediments exploited for sand or water. At other times, the Rhône could turn into a torrential, swift river. This unpredictable and often destructive nature of the river fostered a negative image, contrasting with the perception of the Saône as life supporting. Pierre-Claude Reynard suggests that in Lyon, the symbolic dimension may be the more constant aspect of the complex and changing series of exchanges characteristic of urban river sites. (Reynard 2016)

Like today, Lyon was the second most important urban center of France in the nineteenth century. The town was famous for its silk industry and the revolutionary silk workers who engaged in uprisings in 1831, 1834, and 1848. Until the eighteenth century, water-dependent commerce and trade had concentrated on the Saône or on the right banks of the Rhône. On the left banks, the independent community La Guillotière benefitted from its proximity to the neighboring urban center; it hosted crafts and functions that were difficult to conduct in the crowded city. However, La Guillotière never featured in Lyon's urban development plans before the nineteenth century, much like Munich and Au were divided rather than connected by the Isar.

As the papers in this issue show, natural dynamic was often used as argument for great projects of change. The great flood of 1856 offered the new emperor a chance to display the effectiveness of his young regime in a city that, unlike other cities, was not devastated by the cholera epidemics that ravaged France (Beeck 1948). Apart from rather small outbreaks (1854:525 deaths; 1855:100 deaths), the city proper was not affected by the French epidemics of $1832,1835,1850$, and 1873 . This was mainly due to the good water 
supply. Water taken from the largely unpolluted Rhône upstream of the city supplied the city's pipes. Even the famous physician Robert Koch, when travelling through France in 1884 studying cholera and the countermeasures taken, visited the city to learn why it had not been hit by the disease. ${ }^{1}$ His report from July 1884 illustrates the differences between Lyon and other cities: The city center was located on a narrow, long peninsula between the Rhône and Saône. All waste and wastewater were originally emptied into the two large rivers and thus were quickly removed from the city. Koch also mentioned the city's clean water supply. By 1884, a network of sewers had been built to collect the waste. They emptied into the river close to the confluence, downstream of the city. The suburban areas to the north and west of the centre stood on rocky ground and were therefore protected. The two suburbs to the east, Broteaux and La Guillotière were less favorably endowed and Koch feared that cholera might break out there, as had happened in the past.

The relation of the city and the Rhône changed fundamentally because of population growth and subsequent need of urban land. Lyon, within its present city limits, had about 110,000 inhabitants at the turn of the nineteenth century. By 1860, the number had tripled to about 310,000 . Thereafter, growth decelerated and by the end of the century, about 440,000 people lived in the city. Late in the nineteenth century, demographic, economic and political transformations combined bringing the left bank of the Rhône into the fabric of the city. The three-part evolution was driven by politics, but structured by the river that conditioned projects for the area. The first phase was characterized by great projects that remained plans at a time when political support was lacking, but also because no single idea how such a large river could be integrated to an old city arose. The Second Empire's re-affirmation of authority gave primacy to action, but the actions that most helped the left bank were designed to help the old centre on Presqu'île. The Third Republic firmly urbanised the left bank and brought the Rhône to the centre of the city by investment into public infrastructure that made the river its stage. As in Vienna or Munich, trains had outpaced water-borne transport. Steam and electricity had superseded river for water or power (Reynard 2016). By emphasizing the role of political forces, the case of Lyon helps us understand the dynamics at work also in cities with much less pronounced sifts in governance such as the nobility residences Vienna and Munich.

\section{Brussels and the Senne}

Brussels was a medium-sized city with some 80,000 inhabitants in 1770 . Around 1890, nearly five times as many, about 550,000 inhabitants lived in the centre and the nine main incorporated suburbs. The cross-section in Fig. 5 shows that also this city developed mainly on one bank of the Senne, towards the gentle hills. Just like the entity now known as the state of Belgium, its major city experienced a series of political changes in the late $18^{\text {th }}$ and nineteenth centuries. From 1795 onward, it served for about 20 years as the capital of a French department, then as a province of the Kingdom of the Netherlands before it became the capital of the new Kingdom of Belgium in 1830.

Despite its small size, the Senne and its urban tributaries had served many needs of Brussels before the transformation of the urban water network in the 1860s and 1870s. Its tributaries had been used for fish farming since the Middle Ages. The Senne was the trading route to the Escaut River and further to the North Sea until the construction of an

\footnotetext{
${ }_{1}$ http://edoc.rki.de/documents/rk/510-855-863/PDF/855-863.pdf here 861.
} 
artificial canal in the sixteenth century. It drove mills and served urban commerce. It also determined urban morphology and social structure.

Industrialization commenced in Brussels well before 1850 and proceeded particularly fast in the eastern, hillier part of the town. The western part, which the Senne River crossed, attracted larger industrial complexes (metal factories, textile, and food production etc.). Growing industrial activity contributed to the organic pollution of the Senne (see Deligne 2016). Around 1850, the textile industry alone discharged organic waste estimated at about fifteen tons per day into the streams of three suburbs located immediately south of the city, the equivalent of the domestic organic waste generated by a population of 150,000 inhabitants today (Deligne 2012). The organic pollution caused by industry was estimated to be more than twice the load coming from the population. Glue and gelatin factories, paper mills, breweries and grease and oil factories were the largest polluters. Industrial effluent led to downstream complaints and demanded action (Deligne 2016). However, when the first sewer pipes were built in 1848, their outlet again was, as in all other cases considered in this comparison, the main urban river. Population growth and commerce exacerbated pollution problems. Brussels experienced several cholera epidemics (in 1832, 1849, 1853-55). The first half of the nineteenth century saw increased flooding and rising damage, which resulted in numerous complaints from inhabitants and the formation by urban authorities of several committees.

Urban authorities had to mitigate diverse problems posed by their river in mid-nineteenth century. After intensive debates, they opted for vaulting the Senne in 1865 just before the outbreak of a new cholera epidemic. Following hygienist objectives and demands of urban development, they deemed it the most appropriate solution to eradicate an unhealthy working class quarter in the middle of the city center and to replace it with a modern, representative, and clean urban area.

But hygiene and new urban planning objectives were not the only reason for the decision to put the main stream below ground. Rather, a combination of different drivers had changed the need for waterborne services and the capacity of the river to act as a natural sewer. Prior to 1850 , improved transport enabled easier importation of marine fish while less rigorous observance of Christian fasts led to the decline of local fisheries and fish farming. The discharge of the Senne likely had by then decreased due to water abstraction upstream to feed the Charleroi Canal. This artificial canal opened in 1832. It connected Brussels to the Hainaut coal basin and depleted the river's capacity to flush sewage. As Deligne (2012) concludes, 'One by one, the activities and needs (energy, artisanal, fish farming, domestic, and other uses) that had engendered the necessary coexistence of people and local water up until the end of the eighteenth century disappeared, until finally the authorities were able to cut the last links in the name of public hygiene.' The transformation accomplished between 1867 and 1871 made surface waters largely invisible and disconnected citizens from the local services. Public water taps were rendered redundant after the installation in 1855 of the first communal water distribution system.

Vaulting the Senne from 1867-1871 was the most important and momentous material transformation of Brussels in the nineteenth century. 'The solution was as original as it was radical: burying the river in the urban subsoil, combined with a prestigious, urbanistic operation that would eliminate all the 'unhealthy' quarters in the center, meaning the poor, working-class quarters.' (Deligne 2012) In comparison, the connection between regulating nature and social disciplining of people is most pronounced in Brussels. Urban authorities in the city cared about manure, as long it had a market value, cleaner water was a positive side-effect rather than a goal. That organic pollution decreased is due to innovations in 
manufacturing processes, including recycling and the relocation of industries rather than resulting from government action (Deligne 2016).

\section{Progress and the movement of waters and germs: ingredients of urban transformation}

The four cities we studied have distinct histories and environmental settings, but it is evident that urbanization and industrialization in the nineteenth century was characterized by similar transformations of their aquatic networks. A closer look into the interwoven complex of hydrology, floods and inundation, the outbreak of epidemics, and technical solutions envisaged in nineteenth-century Vienna will illustrate this. By the end of the eighteenth century, the aquatic network had become a 'second nature', a thoroughly changed socio-natural site. Numerous interventions had already taken place.

The way a flood progressed and the resulting damage pattern were influenced by earlier interventions. A thunderstorm with violent cloudburst over the hills adjacent to the city of Vienna ('Wienerwald'-Vienna Woods) to the northwest and west of the city on 29 July, 1785, wreaked havoc in several areas, some of which would later become parts of Vienna. A well-known public official published a detailed account of this devastating flood and offered several precautionary measures. De Luca recommended removing houses from alltoo flood-prone spaces. While another recommendation, deepening and straightening the streams from the headwaters on, would not have had the desired effect, widening the stream courses, which he considered the most important measure, might have been beneficial. The confluence of the Wien River and the Danube lead to backwater formation, which increased the flood height in the adjacent area. From this, de Luca concluded that confluences should be designed with a pointed angle rather than letting two streams meet orthogonally. This makes immediate sense. His fifth proposition is equally valid today: Anything blocking the course of the river should be removed; no houses, edifices, and dams should be built.

While public opinion in the late eighteenth century held that dams were a means to control a river, de Luca called on his experience to advocate the opposite. He was convinced that even the strongest dam cannot keep a torrential river at bay. Nothing can withstand the power of the water. If a dam breaks, the damage will be larger than without a dam in the first place. Bridges over confluences are particularly endangered due to backwater formation. Therefore, all confluences should be converted into gradual ones. Cleaning riverbeds and avoiding obstacles are mentioned as important and, lastly, de Luca recommended opening several channels for the discharge of floodwater (de Luca 1785).

As this account makes clear, by 1785, the watercourses that make up the aquatic network of Vienna had been changed with weirs and artificial mill creeks to allow mills to harvest an artificially created drop. The siting decisions of urbanites and peri-urban rural inhabitants had put them, either because of their ignorance or because of willful acceptance, at considerable risk. Areas with a high water table had been settled, and the general level of building density had removed the possibility that floods could be rendered harmless by letting them move onto large, grassy patches where they would eventually be absorbed by the soil and even give rise to added productivity of the meadows. De Luca recommended passive flood protection by moving away from the water. The onset of even faster demographic growth of Vienna would render such a solution unfeasible and led to more, rather than less, infrastructural interventions into the flow of water. 
Waterpower and process water were one reason for the Viennese to interact with the rivers and streams. Another one came to the attention of urbanites following a new disease that hit Europe at the beginning of the nineteenth century, after decades of the Napoleonic wars had exhausted the continent in terms of resources and the health of its inhabitants.

Karl Ferdinand Kleinert, editor of a regularly published collection of medical reports "Allgemeines Repertorium der gesammten deutschen medizinisch-chirurgischen Journalistik", sensed in 1831 that there was a market for a collection of information on cholera. In its introduction, we learn that by 1831 doctors on the European continent knew that cholera had long been a regular disease in India. A reference to a medical report from 1689 is given. Only when English colonial troops became infected at the beginning of the nineteenth century, did the disease receive attention by European observers and 13 monographs by English doctors were quickly published.

We also learn of a particular natural anomaly, which led to the cholera epidemic in 1817. From 1815 onwards, weather in India had been anomalous. Heavy rains fell during the otherwise dry season and, during the cold period, fogs were prevalent while, during the usually wet season, a drought befell the area. After extraordinary heat in 1816, the first three months of 1817 were particularly wet, with rains pouring at an unprecedented scale, inundating large tracts of land. The following years were a bit better, but the weather patterns continued to be anomalous (Kleinert 1832, pp. 4-5). Today, we know that the eruption of the Indonesian volcano Tambora in 1815 caused this anomaly. The exceptional combination of heat, drought, and wet periods modified the microbial ecology in the Bay of Bengal and the cholera bacterium mutated into a new strain. The local population had no immune response to this new strain and the illness spread across Asia and around the globe (Wood 2014).

In 1831, when cholera hit Vienna for the first time, the medical profession was aware of the danger and was active in the international community of medical professionals to discuss the issue. It was seen as a public health threat to be managed with a Cordon Sanitaire, just as the plague had been managed. However, as cholera spreads water-bound or via excrement-tainted food, a Cordon Sanitaire was necessarily insufficient.

In the summer of 1855 , the disease came back to Vienna. The journal of Vienna's Medical Doctors' Association in 1856 devoted three articles to cholera. To decide in the contemporaneous debate if the disease were contagious or epidemic, the director of a district hospital in Vienna, Raimund Melzer, a highly respected professional who would later become director of a unit at the largest of Vienna's Hospitals, assembled a meticulous documentation of the circumstances of dozens of cases of cholera. It included a discussion of the sanitary provisions available to various people who had contracted the disease, their travel histories, and the people who had been in contact with them. After having laid out the evidence, the author concluded that the disease spreads by travel and excludes a miasmatic origin.

With more frequent, faster, and generally easier travel between settlements, contagious diseases can travel more easily. After a lengthy consideration of the value of positive versus negative evidence, Melzer argued that toilets and sewers have a role in the spreading of the disease. He ruled out the counter-argument that babies, not using toilets, could also be infected and transmit the disease, by observing that their diapers served the same role as toilets and were even more dangerous. Eventually, Melzer concluded that excrement was the carrier of the yet unknown agent of contagion, correctly assessing the transmission of the disease. His list of preventive measures accordingly puts emphasis on the renovation and cleansing of toilets and sewers. But he still assumes airborne 
transmission from the excrement or excrement-tainted matter, and hence, develops a kind of gas mask as a preventive measure (Melzer 1856).

Another article in the same issue by Ludwig Creutzer, the police medical officer of the district of Landstraße, offers not only a demographic and occupational breakdown of the cholera outbreak in the district, but also a topographical analysis. He concluded from his mapping that low-lying areas were the most likely to experience cholera outbreaks (Creutzer 1856).

Similar to de Luca in 1785 , who had pointed out that human interventions such as weirs or dams could increase the flood risk for adjacent areas, nineteenth-century medical experts held that human interventions exacerbated the dangers of natural agency. In the case of cholera, an investment in aquatic infrastructures including sufficient water supply promised to alleviate the problem, and the same was true for weirs, mills, and bridges-taming the waters and harnessing it for particular uses went hand in hand with controlling disease in the urban socio-natural sites.

The process that has been called modernization is fundamentally rooted in anthropogenic changes of the natural environment and the consequences of such interventions. While in Vienna, cholera was used by authorities as the necessary justification for carrying out the costly work of vaulting streams, in Lyon, the flood of 1856 served the same goal. In Brussels, pollution was used for the same purpose. Urban experts, even if they used the incentive structure that floods and diseases offered to further their own causes, reacted to pressing concerns. People died. Infrastructure faltered. With growing and more specialized production, newer effects such as pollution from toxic effluents from the coal-based chemical industry joined old ones such as excrement in need of sewerage. This increasingly burdened the growing cities. While feudal structures had been important for periurban and urban development, their end in the nineteenth century for most cities in Europe meant new freedom, but also new responsibilities for city governments. Changes in infrastructural arrangements, with their concomitant changes of practices, were a reaction to challenges that cities growing within a closer linked world faced.

\section{Conclusion}

Krausmann et al. (2008) have shown that the take-off phase of the Industrial Revolution heavily burdened the pre-industrial agricultural systems and, one can add, forests. The accelerated production was at first very inefficient. Pollution, disease, and environmental degradation ensued from the transformation-driven over-exploitation. As we showed for Vienna, urban areas were hybrid socio-hydrological spaces already in the eighteenth century, as they used their watercourses for many different needs. The growing cities could not but experience themselves as more and more vulnerable to floods and waterborne diseases and the need for action was clear to communes and citizens alike, whose complaints filled books. These ill effects of the take-off phase of the Industrial Revolution made a good cause for social discipline, but also for engineering interventions into the aquatic arrangements of energy provision in cities, changing them profoundly. Coal and the transport networks it allowed had a homogenizing and segregating effect not just on land use, but also on urban watercourses.

While each river-city story is different, the ensuing set of drivers led to similar outcomes. The fossil-based networked cities' waters run either belowground or between concrete walls and dams, their flow regulated by weirs and locks, their energy used for 
large-scale hydropower in some cases, or for flushing wastes towards treatment plants. Their ecology has been thoroughly transformed; their uses are mono-functional. Small preserves of secondary nature or open spaces for recreational use are another result of the transformation, their naturalness confined for the sake of security and prosperity. While aboveground aquatic remains are greatly simplified in their appearance, the sophistication of the underground networks has been greatly increased.

The differences in the transformation process are as interesting as the shared endpoint. Munich had looked more like Venice or Bruges than we can now imagine. Pettenkofer's cholera maps and the waterpower needs of the city combined in Munich to a very long transition period from open Stadtbäche (urban streams) to an underground sewer network. Water as well as electric energy was brought from considerable distance after 1885 and 1894/95, respectively.

Vienna's dense network of smaller and slightly larger streams combined with accessible groundwater led to spatially dispersed development of workshops and factories and, hence, pollution and cholera. While concentration processes during the transformation can be discerned, and while some traces of the water network remain, the quest for freedom from cholera was the driving force behind almost concurrent regulation and sewer-building in Munich. In the small Senne, an array of problems accumulated around the middle of the nineteenth century after industrialization had changed the town earlier than the other cases. Vaulting of the urban section had seemed the logical solution. From the multitude of preindustrial river uses, only its role as sewage receiver remained. Lyon's aquatic network was rather different. As no tributaries existed, urban water demand focused on the two large rivers, which were increasingly brought under control by dikes and concrete embankments.

Multifunctional, if inefficient ways of using the aquatic networks gave way to monofunctional infrastructures. With growing size of the mostly subterranean network infrastructure, maintenance requirements changed. While the millers and fullers, bridge- and weir-builders of the wooden age had dealt with small-scale repair requirements almost constantly, network managers had to deal with wear and tear on a much larger scale. Responsibility for the centralized networks was constrained to the communes themselves, as private capital would not suffice for the necessary large-scale interventions.

The vulnerability of urbanites in Lyon and Vienna, Munich, and Brussels, and probably in many other cities, has become invisible in the transformation. A new cast of professionals now employs skilled workers and large amounts of fossil energy to maintain the functions the streams and rivers have been assigned in the organic machines that now permeate the underground of our cities. However, urbanites have accepted a bill whose footing is yet to come. The size of investments needed to maintain ailing infrastructures make our degree of self-binding to vulnerable networks clearer. The long-term price of stability and freedom from filth has not yet been determined.

Acknowledgments Open access funding provided by University of Klagenfurt. This paper is a product of URBWATER_-Vienna's Urban Waterscape 1683-1918. An environmental history. FWF Austrian Science Fund Grant No. P25796-G18.

Open Access This article is distributed under the terms of the Creative Commons Attribution 4.0 International License (http://creativecommons.org/licenses/by/4.0/), which permits unrestricted use, distribution, and reproduction in any medium, provided you give appropriate credit to the original author(s) and the source, provide a link to the Creative Commons license, and indicate if changes were made. 


\section{References}

Anderson L (1988) Fire and disease: the development of water supply systems in New England. In: Tarr JA, Dupuy G (eds) Technology and the rise of the networked city in Europe and America. Technology and urban growth 7. Temple University Press, Philadelphia, pp 141-142

Backouche I (2000) La Trace du fleuve. La Seine et Paris (1750-1850). Éditions de l'École des Hautes Études en Sciences Sociales, Paris

Backouche I (2008) From parisian river to National Waterway: the social functions of the Seine, 1750-1850. In: Mauch C, Zeller T (eds) Rivers in history: perspectives on waterways in Europe and North America. University of Pittsburgh Press, Pittsburgh, pp 26-40

Barca S (2010) Energy, property, and the industrial revolution narrative. Ecol Econ 70(7):1309-1315

Barles S (2007) Urban metabolism and river systems: an historical perspective-Paris and the Seine, 1790-1970. Hydrol Earth Syst Sci 11:1757-1769

Billen G, Barles S, Chatzimpiros P, Garnier J (2012) Grain, meat and vegetables to feed Paris: where did and do they come from? localising Paris food supply areas from the eighteenth to the twenty-first century. Reg Environ Change 21(2):325-335

Castonguay S, Evenden M (eds) (2012) Urban rivers: remaking rivers, cities and space in Europe and North America. University of Pittsburgh Press, Pittsburgh

Cioc M (2002) The Rhine: an eco-biography, 1815-2000. University of Washington Press, Seattle

Ciriacono S (2006) Hydraulic energy, society and economic growth. In: Dooley BM (ed) Energy and culture. Perspectives on the power to work. Ashgate, Aldershot, pp 19-30

Corfield PJ (2013) Cities in time. In: Clark P (ed) The Oxford handbook of cities in world history. Oxford University Press, Oxford, pp 828-846

Creutzer L (1856) Bericht über die Cholera-Epidemie während des Sommers 1855 im k.k. Polizeibezirke Landstrasse, und Bemerkungen über Prof. Pettenkofer's Ansichten über die epidemische Brechruhr. Zeitschrift der k. k. Gesellschaft der Ärzte zu Wien 12:617-634

Cronon W (1991) Nature's metropolis: Chicago and the great west. W.W. Norton \& Company, London

de Luca I (1785) Zur Wassergeschichte des Landes unter der Ens. Verlag der van Ghelenschen Buchhandlung, Wien

Deleuze G (1995) Negotiations. Columbia University Press, New York

Deligne C (2012) The rivers of Brussels, 1770-1880 transformations of an urban landscape. In: Castonguay $\mathrm{S}$, Evenden M (eds) Urban rivers. Remaking rivers, cities and spaces in Europe and North America., Series history of the urban environmentPittsburgh University Press, Pittsburgh, pp 17-34

Deligne C (2016) Industrialisation, manure and water quality in the 19th century. The Senne River in Brussels as a case study. Water Hist. doi:10.1007/s12685-016-0163-0

Edwards PN (2003) Infrastructure and modernity: force, time, and social organization in the history of sociotechnical systems. In: Misa TJ, Brey P, Feenberg A (eds) Modernity and technology. MIT Press, Cambridge, pp 185-225

Evenden M (2004) Fish versus power. An environmental history of the Fraser river. Cambridge University Press, Cambridge

Fischer-Kowalski M, Haberl H (2007) Socioecological transitions and global change: trajectories of social metabolism and land use. Edward Elgar, Cheltenham

Fradkin P (1981) A river no more: the Colorado River and the West. Knopf, New York

Gandy M (2006) Das Wasser, die Moderne und der Niedergang der bakteriologischen Stadt. In: Frank S, Gandy M (eds) Hyropolis-Wasser und die Stadt der Moderne. Campus, Frankfurt/Main, pp 19-40

Gierlinger S, Haidvogl G, Gingrich S, Krausmann F (2013) Feeding and cleaning the city: the role of the urban waterscape in provision and disposal in Vienna during the industrial transformation. Water Hist 5(2):219-239. doi:10.1007/s12685-013-0075-1

Gingrich S, Haidvogl G, Krausmann F (2012) The Danube and Vienna: urban resource use, transport and land use 1800 to 1910. Reg Environ Change 12:283-294. doi:10.1007/s10113-010-0201-x

Goddard N (2005) Sanitate Crescamus: water supply, sewage disposal and environmental values in a Victorian suburb. In: Schott D, Luckin B, Massard-Guilbaud G (eds) Resources of the city: contributions to an environmental history of modern Europe. Ashgate, Aldershot, pp 132-148

Guillerme AE (1988) The age of water: the urban environment in the North of France, A.D. 300-1800. A\&M University Press, College Station

Haidvogl G, Guthyne-Horvath M, Gierlinger S, Hohensinner S, Sonnlechner C (2013) Urban land for a growing city at the banks of a moving river: Vienna's spread into the Danube island Unterer Werd from the late 17 th to the beginning of the 20th century. Water Hist 5(2):195-217. doi:10.1007/s12685013-0078-y 
Hamlin Ch (1990) A science of impurity. Water analysis in 19th century Britain. University of California Press, Berkeley

Hauer F, Hohensinner S, Spitzbart-Glasl Ch (2016) How water and its use shaped the spatial development of Vienna. Water Hist 1-28. doi:10.1007/s12685-016-0169-7

Hill C (1997) River of sorrow: environment and social control in Riparian North India, 1770-1994. Association for Asian Studies, Ann Arbor

Hoffmann R (2007) Footprint metaphor and metabolic realities. Environmental impacts of medieval European cities. In: Squatriti P (ed) Natures past. The environment and human history. Univ. of Michigan Press, Ann Arbor, pp 288-325

Hoffmann R (2010) Elemental resources and aquatic ecosystems: medieval Europeans and their rivers. In: Tvedt T, Coopey R (eds) A history of water. rivers and society: from early civilizations to modern times. Tauris, London, pp 165-202

Hohensinner S, Herrnegger M, Blaschke AP, Habereder C, Haidvogl G, Hein T, Jungwirth M, Weiß M (2008) Type-specific reference conditions of fluvial landscapes: a search in the past by 3D-reconstruction. Catena 75:200-215

Hohensinner S, Lager B, Sonnlechner Ch, Haidvogl G, Gierlinger S, Schmid M, Krausmann F, Winiwarter V (2013) Changes in water and land: the reconstructed Viennese riverscape from 1500 to the present. Water Hist 5(2):145-172. doi:10.1007/s12685-013-0074-2

in der Beeck M (1948) Die Epidemiologie der Cholera in Frankreich. Zeitschrift für Hygiene und Infektionskrankheiten 127:526-534

Jungwirth M, Haidvogl G, Hohensinner S, Waidbacher H, Zauner G (2014) Österreichs Donau: Landschaft, Fisch, Geschichte. Institut für Hydrobiologie, Wien

Juuti PS, Katko TS, Vuorinen HS (2007) Environmental history of water: global views on community water supply and sanitation. IWA Publishing, London

Kahrl WL (1982) Water and power: the conflict over Los Angeles' water supply in the Owens Valley. The University of California Press, Berkeley

Keeling A (2004) Sink or Swim: water pollution and environmental politics in Vancouver, 1889-1975. BC Studies 142/43:69-101

Keeling A (2005) Urban waste sinks as a natural resource: the case of the Fraser river. Urban History Review/Revue d'Histoire Urbaine 34:58-70

Keene D (2012) Medieval London and its supply hinterlands. Reg Environ Change 12(2):263-281

Kleinert CE (1832) Cholera Orientalis, Extrablatt Zum Allgemeinen Repertorium Der Gesammten Deutschen Medizinisch-Chirurgischen Journalistik I. Heft. Christian Ernst Kollmann, Leipzig

Krausmann F, Schandl H, Sieferle RP (2008) Socio-ecological regime transitions in Austria and the United Kingdom. Ecol Econ 65:187-201. doi:10.1016/j.ecolecon.2007.06.009

Mauch Ch, Zeller T (eds) (2008) Rivers in history. Perspectives on waterways in Europe and North America. University of Pittsburgh Press, Pittsburgh

Melosi M (2000) The sanitary city. Urban infrastructure in America from colonial times to the present. John Hopkins University Press, Baltimore

Melzer R (1856) Die asiatische Brechruhr als Volkskrankheit, ihre Verbreitungsweise, ihre Behandlung und ihr Verhältnis zum Staate. Zeitschrift der k. k. Gesellschaft der Ärzte zu Wien 12:534-616

Misa TJ, Brey P, Feenberg A (2003) Modernity and technology. MIT Press, Cambridge

Nipperdey T (1990) Arbeitswelt und Bürgergeist. Deutsche Geschichte 1866-1918, vol 1. Beck, München

Otero I, Kallis G, Aguilar R, Ruiz V (2011) Water scarcity, social power and the production of an elite suburb: the political ecology of water in Matadepera, Catalonia. Ecol Econ 70(7):1297-1308

Pettenkofer Mv (1855) Untersuchungen und Beobachtungen über die Verbreitungsart der Cholera. Cotta, München

Pløger J (2008) Foucault's dispositif and the city. Plan Theory 7:51-70

Pollack G, Gierlinger S, Haidvogl G, Winiwarter V (2016) Using and abusing a small urban river: the Wien River before and during industrialization. Water Hist. doi:10.1007/s12685-016-0170-1

Porter D (1998) The Thames Embankment: environment, technology, and society in Victorian London. University of Akron Press, Akron

Pritchard SB (2011) Confluence: the nature of technology and the remaking of the Rhône. Harvard University Press, Cambridge

Rautanen S-L, Luonsi A, Nygard H, Vuorinen H, Rajala R (2010) Sanitation, water and health. Environ Hist 16:173-194

Reynard PC (2016) Silent partner: river and city in sequence and context. Water Hist. doi:10.1007/s12685016-0161-2 
Schott D (2007) Stadt und Fluss: Flüsse als städtische Umwelten im 19. und 20. Jahrhundert. In: Herrmann B (ed) Beiträge zum Göttinger Umwelthistorischen Kolloquium 2004-2006. Graduiertenkolleg interdisziplinäre Umweltgeschichte. Universitätsverlag Göttingen, Göttingen, pp 141-162

Schott D, Toyka-Seid M (2008) Die europäische Stadt und ihre Umwelt. Wissenschaftliche Buchgesellschaft, Darmstadt

Steinberg T (1991) Nature incorporated: industrialization and the waters of New England. Cambridge University Press, New York

Tarr JA (1996) The search for the ultimate sink. Urban pollution in historical perspective. University of Akron Press, Akron

Tarr JA (2002) The metabolism of the industrial city: the case of Pittsburgh. J Urban Hist 28:511-545

Tarr JA (2005) The metabolism of the industrial city. The case of Pittsburgh. In: Diefendorf JM, Dorsey K (eds) City, country, empire. Landscapes in environmental history. University of Pittsburgh Press, Pittsburgh, pp 15-37

Tarr JA, Dupuy G (eds) (1988) Technology and the rise of the networked city in Europe and America. Technology and Urban Growth 7. Temple University Press, Philadelphia

Tello E, Ostos JR (2012) Water consumption in Barcelona and its regional environmental imprint: a longterm history (1717-2008). Reg Environ Change 12:347-361. doi:10.1007/s10113-011-0223-Z

Tvedt T, Jakobsson E (2006) Introduction: water history is world history. In: Tvedt T, Jacobsson E (eds) A history of water volume 1: water control and river biographies. Tauris, London, pp ix-xiii

Weigl A (2000) Demographischer Wandel und Modernisierung in Wien. Kommentare zum Historischen Atlas von Wien 1. Picher, Wien

White R (1995) The organic machine: the remaking of the Columbia River. Hill and Wang, New York

Winiwarter V (2000) Where did all the waters go? the introduction of sewage systems in urban settlements. In: Bernhardt C (ed) Environmental problems in European cities in the 19th and 20th century. Waxmann, Münster, pp 105-119

Winiwarter V, Schmid M (2008) Umweltgeschichte als Untersuchung sozionaturaler Schauplätze? Ein Versuch, Johannes Colers, Oeconomia"umwelthistorisch zu interpretieren. In: Knopf T (ed) Umweltverhalten in Geschichte und Gegenwart. Attempto Verlag, Tübingen, pp 158-173

Winiwarter V, Schmid M, Dressel G (2013) Looking at half a millennium of co-existence: the Danube in Vienna as a socio-natural site. Water Hist 5(2):101-119. doi:10.1007/s12685-013-0079-x

Winiwarter V, Haidvogl G, Bürkner M (2016) The rise and fall of Munich's early modern water network: a tale of prowess and power. Water Hist. doi:10.1007/s12685-016-0173-y

Wood GD (2014) Tambora: the eruption that changed the world. Princeton University Press, Princeton

Worster D (1992) Rivers of empire: water, aridity, and the growth of the American west. Oxford Univ. Press, Oxford 